\title{
SISTEMAS DE CALIDAD COMO ESTRATEGIA DE VENTAJA COMPETITIVA EN LA AGROINDUSTRIA ALIMENTARIA
}

\author{
QUALITY SYSTEMS AS STRATEGY FOR COMPETITIVE ADVANTAGE \\ IN THE FOOD AGROINDUSTRY
}

Michaelene Huerta-Dueñas*, S. Alfonso Sandoval-Godoy

\begin{abstract}
Centro de Investigación en Alimentación y Desarrollo, A.C., México, México. Cordinación de Desarrollo Regional, CIAD, A.C. (mihuerta08@gmail.com). (ssandoval@ciad.mx).
\end{abstract}

\begin{abstract}
RESUMEN
Debido a la gran relevancia de los sistemas de calidad en la actual coyuntura internacional de los mercados, la presente investigación realiza una discusión acerca de la implementación de los sistemas de calidad como instrumentos de ventaja competitiva en la agroindustria alimentaria, a fin de establecer un marco de reflexión para el análisis de casos de estudio. Para ello, se realiza una revisión y análisis de la literatura sobre las repercusiones de su uso, su relación con el mercado y sus implicaciones en el sector agroalimentario. A partir de lo anterior se concluye que los sistemas de calidad son una estrategia clave para lograr una mayor ventaja competitiva, siendo estos un requisito imprescindible dentro de la agroindustria alimentaria.
\end{abstract}

Palabras clave: mercado, metodologías de calidad, normatividades de calidad.

\section{INTRODUCCIÓN}

$\mathrm{E}$ 1 actual entorno competitivo de los mercados se caracteriza por una constante globalización que genera cambios en la dinámica mundial de producción y procesamiento. Esta transición incita a los mercados agroalimentarios a transformarse en estructuras oligopólicas, puesto que las estrategias juegan un papel fundamental para las firmas que en ellos compiten (Garza-Lagler, 2015), de tal manera que la calidad se impone como una estrategia que permite la penetración de mercados.

El concepto de calidad es un constructo complejo y polisémico, puesto que es definido e interpretado de diferentes maneras según el ámbito de su análisis.

* Autor responsable * Author for correspondence. Recibido: mayo, 2015. Aprobado: noviembre, 2016.

Publicado como ARTÍCULO en ASyD 15: 19-28. 2018.

\section{Abstract}

Due to the great importance of quality systems in current international market circumstances, this study presents a discussion about the implementation of quality systems as instruments for competitive advantage in the food agroindustry, in order to establish a reflection framework for the analysis of study cases. For this purpose, a literature review and analysis is carried out regarding the repercussions of their use, their relation to the market, and their implications in the agrifood sector. From this it is concluded that quality systems are a key strategy to achieve greater competitive advantage and that they are an essential requisite within the food agroindustry.

Key words: market, quality methodologies, quality regulations.

\section{INTRODUCTION}

$\mathrm{T}$ The current competitive environment in markets is characterized by constant globalization that generates changes in the global dynamics of production and processing. This transition drives agrifood markets to become oligopoly structures, since strategies play a fundamental role for the companies that compete in them (Garza-Lagler, 2015), so that the quality is imposed as a strategy that allows entering markets.

The concept of quality is a complex and polysemic construct, since it is defined and interpreted in different ways according to the sphere of analysis. Throughout time, various authors have attempted to specify its definition; however, this has not been in accordance. The evolution that the term quality has experienced has contributed to the emergence of quality systems. These are the set of regulations and methodologies that are interrelated to direct 
A través del tiempo, diversos autores han tratado de precisar su definición; sin embargo, esta no ha sido concordante. La evolución que ha experimentado el término de calidad ha propiciado el surgimiento de los sistemas de calidad. Estos son el conjunto de normatividades y metodologías que se interrelacionan entre sí para dirigir y controlar los proceso productivos de las empresas, a partir de un enfoque donde prevalece una cultura y orientación hacia la mejora continua y la calidad (Camisón et al., 2009; Álvarez-García et al., 2014). Por su parte, las normatividades de calidad son el cúmulo de certificaciones y acreditaciones que contienen las especificaciones técnicas y los criterios precisos de los procedimientos de gestión de calidad (Organización de las Naciones Unidas para la Alimentación y la Agricultura [FAO], 2004a), mientras que las metodologías de calidad son las técnicas y herramientas ${ }^{1}$ que constituyen la dimensión operativa necesaria para apoyar el aseguramiento de la calidad y la puesta en marcha de los procesos de mejora continua en las empresas (Álvarez-García et al., 2014).

En los últimos años se ha producido un creciente interés por el estudio de los efectos de los sistemas de calidad en empresas con diferentes giros productivos. De hecho, se ha comprobado que tanto las normatividades como las metodologías conllevan al incremento de distintos factores que contribuyen al desempeño operativo; no obstante, algunas investigaciones ponen en entredicho la existencia de implicaciones positivas en la rentabilidad. En el caso de los mercados con estructura oligopólica, como el agroalimentario, la conducta estratégica tiene lugar, de tal modo que los sistemas de calidad se tornan en una estrategia de ventaja competitiva, puesto que son una herramienta de diferenciación, de competencia comercial y de segmentación del mercado.

El objetivo del presente artículo es efectuar una discusión acerca del uso de los sistemas de calidad como instrumentos de ventaja competitiva en las agroindustrias alimentarias, a fin de construir un marco de reflexión para el análisis de futuros casos de estudio.

\section{IMPLICACIONES DE LOS SISTEMAS DE CALIDAD EN LAS EMPRESAS}

Para examinar las implicaciones derivadas del empleo de los sistemas de calidad es necesario analizar individualmente los elementos que los componen, and control the productive processes of enterprises, from an approach where a culture and orientation toward continuous improvement and quality prevails (Camisón et al., 2009; Álvarez-García et al., 2014). In turn, quality regulations are the sum of certifications and accreditations that contain technical specifications and the precise criteria of quality management procedures (Food and Agriculture Organization of the United Nations, [FAO], 2004a), while quality methodologies are the techniques and tools ${ }^{1}$ that constitute the operative dimension necessary to support the assurance of quality and the implementation of processes of continuous improvement in the enterprises (ÁlvarezGarcía et al., 2014).

In recent years a growing interest has been produced over the study of the effects of the quality systems in enterprises with different productive directions. In fact, it has been shown that both the regulations and the methodologies lead to the increase of different factors that contribute to the operative performance; however, some studies question the existence of positive implications in profitability. In the case of markets with an oligopoly structure, such as the agrifood market, strategic behavior takes place, so that quality systems become a strategy for competitive advantage, since they are a tool of differentiation, commercial competition, and market segmentation.

The objective of this article is presenting a discussion about the use of quality systems as instruments for competitive advantage in the dietary agrifood industries, in order to build a reflection framework for the analysis of future study cases.

\section{IMPLICATIONS OF QUALITY SYSTEMS IN ENTERPRISES}

In order to examine the implications derived from the use of quality systems it is necessary to analyze individually the elements that integrate them, both quality regulations and methodologies. This is generated because of the lack of research addressing this theme in an integral manner.

During the last two decades, interest over the study of quality regulations as a factor that contributes to the operative and financial performance has increased. The studies that tackle this relationship stem solely from the analysis of ISO-type standards, 
tanto normatividades como metodologías de calidad. Esto es generado debido a la carencia de investigaciones que aborden esta temática de manera integrada.

Durante las últimas dos décadas ha aumentado el interés por el estudio de las normas de calidad como un factor contribuyente en el desempeño operativo y financiero. Las investigaciones que abordan esta relación parten únicamente del análisis de estándares tipo ISO, la certificación de calidad turística Q y el modelo Europeo de Excelencia (EFQM), sin considerar otras normas de uso común.

Algunos de los estudios que examinan los beneficios derivados de las normatividades de calidad son controversiales. Numerosas investigaciones concluyen que los estándares de calidad ejercen un efecto positivo en la productividad (Sánchez-Ollero et al., 2014), la cadena de suministros (Houshmand y Rakotobe, 2012), la cuota de mercado (Mak, 2011), la mejora continua (Lizarzaburu-Bolaños, 2016), la satisfacción del cliente (Chikuku et al., 2012) y la internalización de las empresas (Botello-Peñaloza, 2016), mientras que otros han llegado a conclusiones dispares con respecto a la rentabilidad (Cuadro 1).

Diversas voces críticas señalan que esta discordia es debida a que los estudios en esta línea no consideran en su análisis los motivos que guían la decisión de certificación, ya que estos pueden estar influyendo en la rentabilidad de las empresas. Según los expertos existen dos grupos de motivaciones: por un lado, las internas, referentes a la mejora de la productividad, la eficiencia y la rentabilidad y, por otro, las externas, relacionadas con las presiones de diversos agentes como los clientes, el gobierno y la competencia. Aquellas empresas que se certifican por razones internas obtienen mejor rentabilidad que las que lo hacen por causas externas. En este sentido, Terziovski y Power (1997) ponen énfasis en la necesidad de desarrollar una fuerte cultura de calidad para que la implementación de certificaciones se traduzca en incrementos en la rentabilidad.

Por otra parte, las metodologías de calidad se relacionan con la eficiencia de los procesos (TolamatlMichcol et al., 2011), la reducción de los tiempos de entrega (Fuente-Aragón de la et al., 2012), la optimización de la cadena de suministros (Jones y Womack, 2012), el incremento de la calidad en los productos (Álvarez-García et al., 2014), el aumento de la rentabilidad (Oliva-Olivera, 2013) y el mejoramiento continuo (Álvarez-García et al., 2014). the Q tourism quality certification, and the European Excellence model (EFQM), without taking into consideration other norms of common use.

Some of the studies that examine the benefits derived from quality regulations are controversial. Many studies conclude that quality standards exert a positive effect on productivity (Sánchez-Ollero et al., 2014), the supply chain (Houshmand and Rakotobe, 2012), the market quota (Mak, 2011), continuous improvement (Lizarzaburu-Bolaños, 2016), client satisfaction (Chikuku et al., 2012), and internalization of enterprises (Botello-Peñaloza, 2016), while others have reached dissimilar conclusions regarding profitability (Table 1).

Diverse critical voices point out that this discord is because the studies in this line do not consider in their analyses the motives that guide the decision of certification, since these can be influencing the profitability of the companies. According to the experts, there are two groups of motivations: on the one side, the internal ones, referring to improvement in productivity, efficiency and profitability, and on the other, the external ones, related to the pressures from various agents such as clients, the government and the competition. The enterprises that are certified because of internal reasons obtain higher profitability than those that do it because of external reasons. In this sense, Terziovski and Power (1997) emphasize the need to develop a strong quality culture for the implementation of certifications that translate into increases in profitability.

On the other hand, quality methodologies are related to efficiency in processes (Tolamatl-Michcol et al., 2011), reduction of delivery times (FuenteAragón de la et al., 2012), optimization in the supply chain (Jones and Womack, 2012), increase in the product quality (Álvarez-García et al., 2014), increase in profitability (Oliva-Olivera, 2013), and continuous improvement (Álvarez-García et al., 2014).

Heras et al. (2009) maintain that the quantitative or hard methodologies, such as the analysis of the mode and effect of faults, six sigma, and the statistical control of the process, are linked to a significant improvement in entrepreneurial performance. It should be highlighted that the hard techniques and tools are used less often than the soft, such as systems of complaints and suggestions and improvement groups, since they generally ignore and require greater 
Cuadro 1. Relación entre las certificaciones de calidad y la rentabilidad.

Table 1. Relation between quality certifications and profitability.

\begin{tabular}{|c|c|c|c|}
\hline Referencia & Metodología y ámbito & Objetivos & Conclusión \\
\hline Lo et al. (2011) & $\begin{array}{l}193 \text { entrevistas a empresas } \\
\text { manufactureras en China }\end{array}$ & $\begin{array}{l}\text { Examinar el impacto de cinco } \\
\text { certificaciones distintas en la } \\
\text { rentabilidad. }\end{array}$ & $\begin{array}{l}\text { El número de certificaciones obtenidas } \\
\text { no se correlaciona con los resultados } \\
\text { financieros de las empresas. }\end{array}$ \\
\hline $\begin{array}{l}\text { Moura-Duarte et } \\
\text { al. (2011) }\end{array}$ & $\begin{array}{l}\text { Base de datos de } 1200 \text { empresas } \\
\text { manufactureras en Brasil }\end{array}$ & $\begin{array}{l}\text { Examinar la relación de ISO } 9000 \\
\text { con el desempeño financiero. }\end{array}$ & $\begin{array}{l}\text { ISO } 9000 \text { tiene una relación negativa } \\
\text { con el desempeño financiero. }\end{array}$ \\
\hline $\begin{array}{l}\text { Chikuku et al. } \\
\text { (2012) }\end{array}$ & $\begin{array}{l}26 \text { encuestas a empresas } \\
\text { manufactureras en Zimbabue }\end{array}$ & $\begin{array}{l}\text { Analizar y determinar los } \\
\text { beneficios de la certificación ISO. }\end{array}$ & $\begin{array}{l}\text { ISO beneficia la productividad y } \\
\text { competitividad; sin embargo, tiene } \\
\text { un efecto negativo en el desempeño } \\
\text { financiero. }\end{array}$ \\
\hline $\begin{array}{l}\text { Tarí-Guilló y } \\
\text { Pereira-Moliner } \\
\text { (2012) }\end{array}$ & $\begin{array}{l}\text { Base de datos de } 219 \text { empresas } \\
\text { del sector de servicios en } \\
\text { España. }\end{array}$ & $\begin{array}{l}\text { Analizar la rentabilidad de las } \\
\text { empresas certificadas contra las no } \\
\text { certificadas. }\end{array}$ & $\begin{array}{l}\text { Las empresas certificadas tienen } \\
\text { mayor rentabilidad y ventas totales en } \\
\text { comparación a las no certificadas. }\end{array}$ \\
\hline $\begin{array}{l}\text { Morelos-Gómez et } \\
\text { al. (2013) }\end{array}$ & $\begin{array}{l}\text { Base de datos de } 25 \text { empresas } \\
\text { localizadas en Colombia. }\end{array}$ & $\begin{array}{l}\text { Evaluar los indicadores de } \\
\text { productividad y utilidad financiera } \\
\text { en empresas certificadas en ISO } \\
9001 \text {. }\end{array}$ & $\begin{array}{l}\text { La certificación ISO beneficia la } \\
\text { productividad, utilidad bruta, estructura } \\
\text { financiera y margen operacional. }\end{array}$ \\
\hline $\begin{array}{l}\text { Santamaría-Escobar } \\
\text { y Pertuz-Martínez } \\
(2013)\end{array}$ & $\begin{array}{l}\text { Base de datos de } 2 \text { empresas de } \\
\text { servicios en Colombia. }\end{array}$ & $\begin{array}{l}\text { Determinar los principales } \\
\text { cambios en el desempeño } \\
\text { empresarial después de la } \\
\text { implementación de certificaciones. }\end{array}$ & $\begin{array}{l}\text { La transformación de las empresas hacia } \\
\text { un enfoque de procesos es la clave para } \\
\text { mejorar el desempeńo empresarial. }\end{array}$ \\
\hline Kiplagat (2014) & $\begin{array}{l}\text { Base de datos de } 33 \text { empresas } \\
\text { manufactureras en Kenia }\end{array}$ & $\begin{array}{l}\text { Examinar el impacto de ISO en el } \\
\text { rendimiento financiero. }\end{array}$ & $\begin{array}{l}\text { La certificación ISO conlleva a mejorar } \\
\text { el rendimiento financiero. }\end{array}$ \\
\hline Mahnaz (2014) & $\begin{array}{l}95 \text { cuestionarios a empresas } \\
\text { de manufactura y servicio en } \\
\text { Pakistán. }\end{array}$ & $\begin{array}{l}\text { Determinar si ISO } 9000 \text { impacta } \\
\text { favorablemente en el rendimiento } \\
\text { financiero de las empresas } \\
\text { pequeñas. }\end{array}$ & $\begin{array}{l}\text { No es posible concluir que la } \\
\text { certificación ISO } 9000 \text { conlleve un } \\
\text { impacto favorable en el rendimiento } \\
\text { financiero de las empresas pequeñas. }\end{array}$ \\
\hline $\begin{array}{l}\text { Pérez-Méndez y } \\
\text { Machado-Cabezas } \\
\text { (2015) }\end{array}$ & $\begin{array}{l}450 \text { cuestionarios a empresas } \\
\text { del sector manufacturero y de } \\
\text { servicios en España. }\end{array}$ & $\begin{array}{l}\text { Analizar si el enfoque estratégico } \\
\text { de los sistemas de gestión mejora } \\
\text { el rendimiento financiero. }\end{array}$ & $\begin{array}{l}\text { Efecto positivo en el empleo de sistemas } \\
\text { de calidad en relación al rendimiento } \\
\text { empresarial. }\end{array}$ \\
\hline $\begin{array}{l}\text { Smith-Ramírez } \\
(2015)\end{array}$ & $\begin{array}{l}42 \text { cuestionarios a empresas del } \\
\text { sector manufacturero en México }\end{array}$ & $\begin{array}{l}\text { Evaluar el impacto de la estrategia } \\
\text { de calidad en factores del } \\
\text { desempeño empresarial. }\end{array}$ & $\begin{array}{l}\text { La implementación de la estrategia de } \\
\text { calidad tiene un impacto positivo en el } \\
\text { desempeño empresarial. }\end{array}$ \\
\hline $\begin{array}{l}\text { Botello-Peñaloza } \\
(2016)\end{array}$ & $\begin{array}{l}\text { Base de datos de } 1960 \text { empresas } \\
\text { manufactureras en Colombia }\end{array}$ & $\begin{array}{l}\text { Evaluar el impacto de las } \\
\text { certificaciones de calidad en la } \\
\text { internalización. }\end{array}$ & $\begin{array}{l}\text { La tenencia de certificaciones incrementa } \\
\text { la probabilidad de que una empresa } \\
\text { exporte. }\end{array}$ \\
\hline $\begin{array}{l}\text { Cândido et al. } \\
\text { (2016) }\end{array}$ & $\begin{array}{l}\text { Base de datos de } 143 \text { empresas } \\
\text { manufactureras en Portugal }\end{array}$ & $\begin{array}{l}\text { Evaluar cómo la descertificación } \\
\text { de ISO } 9001 \text { afecta el rendimiento } \\
\text { financiero. }\end{array}$ & $\begin{array}{l}\text { La descertificación no conduce a ningún } \\
\text { rendimiento financiero anormal frente a } \\
\text { las empresas con ISO } 9001 \text {. }\end{array}$ \\
\hline
\end{tabular}

Fuente: elaboración propia. Source: authors' elaboration.

Heras et al. (2009) sostienen que las metodologías de tipo cuantitativo, o duras, como el análisis de modo y efecto de fallas, seis sigma y el control estadístico del proceso, se vinculan con una mejora significativa en el desempeño empresarial. Cabe resaltar que las técnicas y herramientas duras son menos empleadas que las blandas, como los sistemas de quejas y sugerencias y los grupos de mejora, puesto financial investment, time, specialized knowledge and experience. Likewise, Heras et al. (2011) state that qualitative methodologies tend to be used by companies with quality management systems based on the ISO norms, while the quantitative ones tend to be implemented in enterprises that adopt the European Excellence model. These differences can be explained because ISO is focused on the processes 
que generalmente se desconocen y requieren mayor inversión financiera, tiempo, conocimiento especializado y experiencia. Asimismo, Heras et al. (2011) afirman que las metodologías cualitativas tienden a ser utilizadas por empresas con sistemas de gestión de calidad basados en las normas ISO, en tanto que las cuantitativas tienden a implementarse en empresas que adoptan el modelo Europeo de Excelencia. Dichas diferencias pueden ser explicadas debido a que ISO se enfoca en los procesos y el cliente, mientras que EFQM tiene una perspectiva más amplia y completa.

\section{EL MERCADO Y SU RELACIÓN CON LOS SISTEMAS DE CALIDAD}

El mercado es una entidad compleja y dinámica, estudiado en la teoría de la Organización Industrial. Según Shepherd (1999), es un grupo de compradores y vendedores que intercambian bienes altamente sustituibles entre sí. Definir el mercado significa delinear sus límites, de manera que contenga todos los bienes sustitutos y excluya todos aquellos que no lo son. Dicha delimitación implica examinar las condiciones de demanda que incluye la zona de decisión del consumidor respecto a un producto. De acuerdo con Shepherd y Shepherd (2003), los mercados se estiman a partir de las siguientes dimensiones: área geográfica, elasticidad cruzada y tipo y precio del producto.

Una vez definido el mercado se puede evaluar su estructura. Los principales elementos para determinar el tipo de estructura son: cuota de mercado, concentración y número de rivales comparables, y barreras de entrada (Shepherd, 1999). Conforme a la teoría de la economía, los tipos de estructura de mercado son la competencia perfecta, el monopolio y el oligopolio (Figura 1).

La estructura oligopólica es la que resulta de mayor utilidad para entender el funcionamiento de los actuales mercados; de hecho, las industrias agroalimentarias tienden a identificarse cada vez más con este tipo de esquema (Taddei, 2008; Garza-Lagler, 2015), de tal forma que en esta la conducta estratégica tiene lugar, puesto que las firmas generan alto grado de competitividad mediante características diferenciales sobre la competencia.

$\mathrm{Al}$ respecto, Porter (1987) identifica que los costos bajos y la diferenciación de los productos son dos and the client, while the EFQM has a broader and more complete perspective.

\section{THE MARKET AND ITS RELATIONSHIP WITH QUALITY SYSTEMS}

The market is a complex and dynamic entity, studied in the theory of Industrial Organization. According to Shepherd (1999), it is a group of buyers and sellers that exchange goods that are highly replaceable between each other. Defining the market means delineating its limits, so that it contains all the substitute goods and excludes all those that are not. This delimitation implies examining the conditions of demand that include the decision zone of the consumer with regards to a product. According to Shepherd and Shepherd (2003), the markets are estimated based on the following dimensions: geographic area, crossed elasticity, and type and price of the product.

Once the market is defined, its structure can be evaluated. The main elements to determine the type of structure are: market quota, concentration and number of comparable rivals, and entry barriers (Shepherd, 1999). According to the economic theory, the types of market structure are perfect competition, monopoly and oligopoly (Figure 1).

The oligopoly structure is the one that is of greater use to understand the functioning of current markets; in fact, the agrifood industries tend to identify increasingly more with this type of scheme (Taddei, 2008; Garza-Lagler, 2015), so that strategic behavior takes place in it, since enterprises generate a high degree of competitiveness through differential characteristics on the competition.

In this regard, Porter (1987) identifies that low costs and the differentiation of products are two types of competitive advantages. In turn, these generate three types of generic strategies: approach, leadership in costs and differentiation, with the last two having a close relationship with quality and, therefore, with quality management systems. It can be thought that the differentiation strategy is linked more to quality than to leadership in costs; however, the praxis demonstrates that enterprises can produce with quality systems at low costs. In the current environment the enterprises that do not integrate both tactics to their strategic planning face disadvantages before their competitors, since the leader with these 


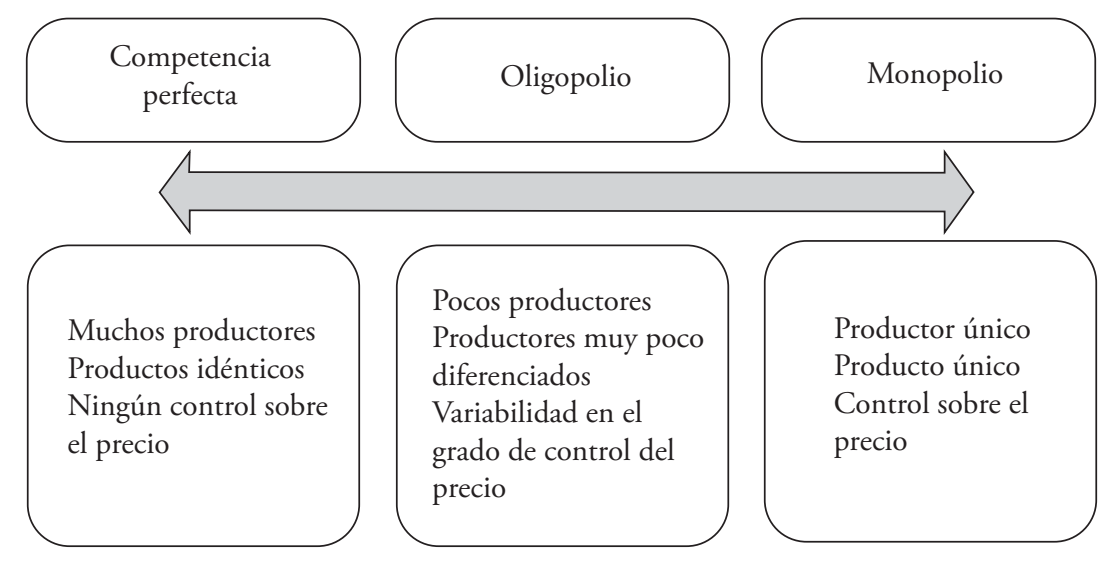

Fuente: Garza-Lagler (2015) con base en Bueno y Morcillo (1993). * Source: GarzaLagler (2015) based on Bueno and Morcillo (1993).

Figura 1. Tipos de estructuras de mercado Figure 1. Types of market structures.

tipos de ventajas competitivas. A su vez, estas generan tres tipos de estrategias genéricas: enfoque, liderazgo en costos y diferenciación, teniendo estas últimas dos una íntima relación con la calidad y, por ende, con los sistemas de gestión de calidad. Se puede pensar que la estrategia de diferenciación se vincula mayormente con la calidad que el liderazgo en costos; sin embargo, la praxis demuestra que las empresas pueden producir con sistemas de calidad a bajos costos. En el actual entorno las empresas que no integren ambas tácticas en su planeación estratégica se enfrentarán con desventaja ante sus competidores, dado que el líder con dichas características poseerá un mayor potencial para posicionar sus productos en un plano más competitivo que sus rivales.

Asimismo, Boyer y Freyssenet (2003) reconocen en algunos segmentos de la industria, seis estrategias de rentabilidad en función del mercado: calidad en los productos, diversidad de la oferta, flexibilidad productiva, innovación, reducción permanente de costos y volumen de producción. Ciertamente, es imposible que todas las empresas adopten y combinen las mismas tácticas, puesto que deben resolver problemas de diferente naturaleza en tiempos distintos y con recursos diversos. No obstante, en los mercados altamente exigentes, como los internacionales y los de productos de gama alta, se destaca que la calidad desempeña un papel mayor que las otras estrategias. En los mercados de exportación, Botello-Peñaloza (2016) señala que los sistemas de calidad ${ }^{2}$ tienen un characteristics will have higher potential to position its products in a more competitive plane than its rivals.

Likewise, Boyer and Freyssenet (2003) recognize, in some segments of the industry, six profitability strategies in function of the market: quality in the products, diversity in the offer, productive flexibility, innovation, permanent cost reduction, and production volume. Certainly, it is impossible for all enterprises to adopt and combine the same tactics, for they must solve problems of different nature at different times and with diverse resources. However, in highly demanding markets, such as international ones and those of high spectrum products, it stands out that quality carries out a greater role than the other strategies. In export markets, Botello-Peñaloza (2016) points out that quality systems ${ }^{2}$ have a differentiating role, in addition to a positive impact on the internationalization of the enterprises, since their probability of insertion in international markets increases in $20 \%$, differing from the ones that lack them.

\section{QUALITY SYSTEMS IN FOOD AGROINDUSTRIES}

The strong food crises have caused for the requirements from buyers to increase and diversify, since their demands are increasingly stricter, critical and fragmented, since they require quality foods that are innocuous, nutritive, low fat, at accessible prices, 
papel diferenciador, además de un impacto positivo en la internacionalización de las empresas, ya que estos aumentan $20 \%$ la probabilidad de inserción en los mercados internacionales, diferenciándose de los que carecen de estos.

\section{SisTEMAS DE CALIDAD EN LAS AGROINDUSTRIAS ALIMENTARIAS}

Las fuertes crisis alimentarias han provocado que las exigencias de los compradores se incrementen y diversifiquen, ya que sus demandas son cada vez más exigentes, críticas y fragmentadas, pues reclaman alimentos de calidad, inocuos, nutritivos, bajos en grasa, a precios accesibles, de elaboración sencilla, trazables, entre otras muchas características. Ante esta situación, las industrias dedicadas a la elaboración de alimentos modifican sus sistemas tecno-productivos mediante la instrumentación de sistemas de calidad -normas y metodologías- que conllevan al aseguramiento de la calidad.

En la industria alimentaria los sistemas de calidad son parte del nuevo marco regulatorio que surge a partir de las transformaciones del régimen del comercio internacional (McNair, 2012). Estos son creados por grandes corporaciones, con la finalidad de categorizar, distinguir y proteger distintos productos de las imitaciones, y así legitimar el alza de su valor comercial al asegurar mayor valor agregado (Rodríguez-Gómez, 2012). Al hacerlo, se busca también brindar a los distintos actores de los sistemas agroalimentarios nuevas oportunidades de mercado y ventajas competitivas al responder a las demandas de los consumidores.

Lo anterior da origen a la proliferación de signos de calidad, como marcas, denominaciones de origen y estándares de calidad. Algunos de estos son de carácter obligatorio como: las buenas prácticas agrícolas, las buenas prácticas de manufactura y el manejo integrado de plagas; y otros son voluntarios, por ejemplo: las normatividades ISO, el análisis de peligros y puntos criticos del control (HACCP), y la norma internacional para los alimentos (IFS). Sin embargo, la índole y el tipo de normativa dependerán de las exigencias impuestas por cada mercado, ya que estas no son aplicables a cualquier industria, cultura y entorno. En el caso de México, las certificaciones más sobresalientes para el sector agroindustrial alimentario son: las Normas Mexicanas, las Normas Oficiales Mexicanas of simple elaboration, traceable, among many other characteristics. Facing this situation, the industries devoted to food elaboration modify their technoproductive systems through the implementation of quality systems -regulations and methodologiesthat lead to the assurance of quality.

In the food industry quality systems are part of the new regulatory framework that emerges from transformations of the international commerce regime (McNair, 2012). They are created by large corporations, with the aim of categorizing, distinguishing and protecting different products from imitation, and thus legitimizing the increase in their commercial value when ensuring a higher added value (Rodríguez-Gómez, 2012). When doing this, there is also an attempt to provide the different actors in agrifood systems with new market opportunities and competitive advantages when responding to consumers' demands.

This gives rise to the proliferation of quality signs, such as brands, origin denominations, and quality standards. Some of these are of mandatory nature, such as: good agricultural practices, good manufacture practices, and integrated pest management; and others are voluntary, for example: ISO regulations, Hazard Analysis and Critical Control Points (HACCP), and international food standards (IFS). However, the nature and type of regulations will depend on the requirements imposed by each market, since these are not applicable to any industry, culture and environment. In the case of México, the most outstanding certification for the food agroindustry are: the Mexican Regulations, the Mexican Official Norms (Normas Oficiales Mexicanas, NOM), Supreme Quality México (México Calidad Suprema, MCS), and the certification of Federal Inspection Type (Tipo Inspección Federal, TIF).

Concerning quality methodologies, the literature does not document the types of techniques and tools used in food agroindustries. In turn, it should be highlighted that quality standards are not regulated by specific methodologies and their use depends on the particular needs of each industry. Despite this, in the manufacturing and services sector, various authors (Dale and Mcquater, 1998; Heras et al., 2009; Álvarez-García et al., 2014) report the use of some methodologies such as: slender manufacture, seven quality tools, disciplines for problem resolution, and benchmarking, among others. 
(NOM), México Calidad Suprema (MCS) y la certificación de Tipo Inspección Federal (TIF).

En lo concerniente a las metodologías de calidad, la literatura no documenta el tipo de técnicas y herramientas empleadas en las agroindustrias alimentarias. A su vez, cabe resaltar que los estándares de calidad no son regulados por metodologías en específico y su uso depende de las necesidades particulares de cada industria. A pesar de esto, en el ámbito manufacturero y de servicios diversos autores (Dale y Mcquater, 1998; Heras et al., 2009; Álvarez-García et al., 2014) reportan el uso de algunas metodologías como: manufactura esbelta, siete herramientas de calidad, disciplinas para la resolución de problemas y benchmarking, entre otras.

Así también, es importante mencionar que la implementación de sistemas de calidad ha ido en aumento, aunque su empleo es todavía limitado y restringido para unas cuantas, en especial en países de menor desarrollo (FAO, 2004b; FAO, 2006; López-Palacios et al., 2010; Álvarez-García et al., 2014). La FAO (2006) sostiene que esta problemática se debe a la falta de los siguientes recursos: infraestructura productiva, capacidad económica, disponibilidad de insumos de calidad, proveedores certificados y con sistemas de trazabilidad, homogeneidad de las normatividades, actualización de las normas, colaboración con centros de investigación y apoyos gubernamentales.

Con la intención de atender esta problemática, el gobierno mexicano brinda financiamiento a los productores y empresarios a través del Plan Nacional de Desarrollo 2013-2019. Estos apoyos son otorgados para infraestructura, equipamiento y asistencia técnica (Secretaría de Hacienda y Crédito Púbico [SHCP], 2013). Del mismo modo, mediante el Programa Sectorial de Desarrollo Agropecuario, Pesquero y Alimentario 2013-2018 y el Plan Nacional de Desarrollo 2013-2018, la SAGARPA (Secretaría de Agricultura, Ganadería, Desarrollo Rural, Pesca y Alimentación) otorga recursos económicos a las industrias cárnicas para mejorar, renovar o construir instalaciones que se incorporen a la certificación TIF (Fideicomiso de Riesgo Compartido [FIRCO], 2014).

\section{Conclusiones}

Los sistemas de calidad fungen como uno de los más importantes principios reconfiguradores de los mercados mundiales, puesto que generan cambios socioeconómicos, culturales y políticos.
Likewise, it is important to mention that the implementation of quality systems has been increasing, even when their use is still limited and restricted to a few, especially in less developed countries (FAO, 2004b; FAO, 2006; López-Palacios et al., 2010; Álvarez-García et al., 2014). FAO (2006) maintains that this problematic is due to the lack of the following resources: productive infrastructure, economic capacity, availability of quality inputs, certified suppliers and with traceability systems, homogeneity of regulations, updating of regulations, collaboration with research centers and government backing.

With the intention of addressing this problematic, the Mexican government provides financing to producers and entrepreneurs through the National Development Plan 2013-2019. These supports are granted for infrastructure, equipment and technical assistance (Secretaría de Hacienda y Crédito Púbico [SHCP], 2013). Likewise, through the Sectorial Agricultural and Livestock, Fishery and Food Program (Programa Sectorial de Desarrollo Agropecuario, Pesquero y Alimentario) 2013-2018, and the National Development Plan 2013-2018, the SAGARPA (Ministry of Agriculture, Livestock Production, Rural Development, Fishing and Food, Secretaría de Agricultura, Ganadería, Desarrollo Rural, Pesca and y Alimentación) grants economic backing to meat industries to improve, renovate or build facilities that become incorporated into the TIF certification (Shared Risk Fund, Fideicomiso de Riesgo Compartido [FIRCO], 2014).

\section{ConClusions}

Quality systems serve as one of the most important reconfiguring principles of world markets, since they generate socioeconomic, cultural and political changes.

Within markets, especially those with oligopoly structure, the companies adopt different strategic behaviors for their survival and success. According to the theory of Industrial Organization, the type of market is determinant to define the type of competitive strategy, so that in the agrifood markets industries adopt the quality strategy with higher frequency through the management of different quality assurance systems. This is the result of diverse food crises, new consumption habits, clients' demands, intervention by public policies, 
Dentro los mercados, en especial aquellos con estructura oligopólica, las firmas adoptan distintas conductas estratégicas para su supervivencia y éxito. De acuerdo con la teoría de la Organización Industrial, el tipo de mercado es determinante para definir el tipo de estrategia competitiva, por lo que en los mercados agroalimentarios las industrias adoptan con mayor frecuencia la estrategia de calidad a través de la gestión de distintos sistemas de aseguramiento de la calidad. Lo anterior es resultado de las diversas crisis alimentarias, los nuevos hábitos de consumo, las exigencias de los clientes, la intervención de políticas públicas y los avances de conocimiento científico. Asimismo, los sistemas de calidad son una premisa obligatoria para aquellas firmas que deseen exportar sus productos a nuevos mercados.

De la discusión recogida de los múltiples autores se infiere que tanto las normatividades como las metodologías de calidad se vinculan de manera positiva con los resultados operacionales de las empresas, puesto que estos incrementan los niveles de productividad, la mejora continua, la eficiencia en la cadena de suministros, entre otros factores. No obstante, la relación de estos con el desempeño financiero es un tema controversial y aún estudiado.

Por todo lo anteriormente expuesto se puede concluir que los sistemas de calidad en las agroindustrias alimentarias son una estrategia de competencia que permite generar una mayor ventaja competitiva y mejorar el posicionamiento de las empresas sobre las firmas rivales.

\section{Notas}

${ }^{1}$ Las técnicas de calidad son los procedimientos necesarios para alcanzar un objetivo, tales como: seis sigma y kaizen. Las herramientas de calidad son los instrumentos que se utilizan para llevar a cabo una actividad; por ejemplo, las siete herramientas de calidad y el poka-yoke. Quality techniques are the procedures necessary to reach an objective, such as: six sigma and kaizen. Quality tools are instruments that are used to carry out an activity; for example, the seven quality tools and the poka-yoke.

${ }^{2}$ Cabe señalar que las empresas ejecutan la estrategia de calidad mediante la implementación de diversos sistemas de calidad en sus procesos, procedimientos y productos. It should be pointed out that the enterprises execute the quality strategy through the and advances in scientific knowledge. Also, quality systems are a mandatory premise for the companies that wish to export their products to new markets. From the discussion gathered from multiple authors, it is inferred that both quality regulations and methodologies are positively linked with operational results from the enterprises, since these increase the levels of productivity, the continuous improvement, the efficiency in the supply chain, among other factors. However, the relationship of these with the financial performance is a controversial issue that is still being studied.

Because of all of this, it can be concluded that quality systems in food agroindustries are a competition strategy that allow generating a greater competitive advantage and improving the positioning of companies over rival firms.

$$
\text { - End of the English version - }
$$

implementation of various quality systems in their processes, procedures and products.

\section{Literatura Citada}

Álvarez-García, José, Mercedes Vila-Alonso, José Antonio FraizBrea, y María de la Cruz del Río-Rama. 2014. Relación entre herramientas y factores críticos de la calidad. Revista Europea de Dirección y Economía de la Empresa. Vol. 23, Núm. 2

Botello-Peñaloza, Héctor Alberto. 2016. Las certificaciones de calidad y la internalización de las firmas industriales colombianas. Suma de Negocios. Vol. 7, Núm. 16.

Boyer, Robert, y Michel Freyssenet. 2003. Los modelos productivos. España, Editorial Fundamentos. Traductor Tocut Eveline, $155 \mathrm{p}$.

Bueno, Eduardo, y Patricio Morcillo. 1993. Fundamentos de Economia y Organización Industrial, España, McGraw-Hill. 448 p.

Camisón, Cesar, Montserrat Boronat-Navarro, Ana Villar-López, y Alba Puig-Denia. 2009. Sistemas de gestión de la calidad y desempeño: Importancia de las prácticas de gestión del conocimiento y de I+D. Revista Europea de Dirección y Economía de la Empresa. Vol. 18, Núm. 1.

Cândido, Carlos, Luís Coelho, y Rúben Peixinho. 2016. The financial impact of withdrawn ISO 9001 certificate. International Journal of Operations \& Production Management. Vol. 36, Núm. 1.

Chikuku, Tauyanashe, Simon Chinguwa, y Muchumairi Macheka. 2012. Evaluation of the impact of obtaining ISO 9001:2008 Quality Management System (QMS) certifications by manufacturing companies in Zimbabwe. International Journal of Engineering Science and Technology. Vol. 4, Núm. 8.

Dale, Barrie, y Ruth Mcquater. 1998. Managing Business Improvement and Quality: Implementing key tools and techni- 
ques, Inglaterra, Blackwell Business. 208 p.

FAO. 2006. Calidad e inocuidad en las cadenas latinoamericanas de comercialización de alimentos. Roma, FAO

FAO. 2004b. Calidad y competitividad de la agroindustria rural de América Latina y el Caribe. Roma, FAO,

FAO. 2004a. Las normas sociales y ambientales, la certificación y el etiquetado de cultivos comerciales. Roma, FAO.

FIRCO. 2014. Concepto de incentivo para infraestructura y equipamiento para establecimientos Rastros TIF Municipales 2014. México

Fuente-Aragón de la, María Victoria, María Alonso Manzanedo, y Eloy Hernández. 2012. Optimización de operaciones mediante la técnica SMED en una empresa de envases metálicos. XVI Congreso de Ingeniería de Organización. Conferencia llevada a cabo en el $6^{\text {th }}$ International Conference on Industrial Engineering and Industrial Management, España, julio de 2012.

Garza-Lagler, María Cristina. 2015. Investigación y desarrollo como barreras de entrada a nuevos competidores. El caso de las agroempresas de trigo del Valle Yaqui, Sonora, México, Centro de Investigación en Alimentación y Desarrollo. 108 p.

Heras, Inaki, Frederic Marimon, y Martí Casadesús. 2009. Impacto competitivo de las herramientas para la gestión de la calidad. Cuadernos de Economía y Dirección de las Empresas. Vol. 12, Núm. 41.

Heras, Iñaki, Frederic Marimon, y Martí Casadesús. 2011. Impact of quality improvement tools on the performance of firms using different quality management systems. Innovar. Vol. 21, Núm. 42.

Houshmand, Ali, y Thierry Rakotobe. 2012. Integrating the supply chain management and continuous quality improvement approaches by use of the integrated supply chain structural analysis method. Quality Engineering. Vol. 13, Núm. 1.

Jones, Daniel, y James Womack. 2012. Lean thiking: Cómo utilizar el pensamiento Lean para eliminar los despilfarros y crear valor en la empresa, Espańa, Grupo Planeta. 504 p.

Kiplagat, Rebeca. 2014. Impact of ISO 9001 certification on financial performance of commercial state corporations in Kenya, University of Nairobi, Kenya, 59 p.

Lizarzaburu-Bolaños, Edmundo. 2016. La gestión de la calidad en Perú: Un estudio de la norma ISO 9001, sus beneficios y los principales cambios en la versión 2015. Universidad \& Empresa. Vol.18, Núm. 30.

Lo, Chris, Andy Yeung, y Edwin Cheng. 2011. Meta-standards, financial performance and senior executive compensation in China: An institutional perspective. International Journal of Production Economics. Vol. 129, Núm. 1.

López-Palacios, María Guadalupe, Manrrubio Muñoz-Rodríguez, Juan Antonio Leos-Rodríguez, y Fernando CervantesEscoto. 2010. Innovación en valor en la industria cárnica bovina mexicana: Estrategias que adoptan los líderes de Mercado. Revista Mexicana de Ciencias Pecuarias. Vol. 1, Núm. 4.

Mahnaz, Fatima. 2014. Impact of ISO 9000 on business performance in Pakistan: Implications for quality in developing countries. Quality Management Journal. Vol. 21, Núm. 1.

Mak, Barry. 2011. ISO certification in the tour operator sector. International Journal of Contemporary Hospitality Management. Vol. 23, Núm. 1.

McNair, Amber. 2012. La nueva normatividad agrícola y la paradoja de la calidad: Un estudio de caso de Michoacán. In:
Appendini Kirsten, y Rodríguez-Gómez Guadalupe (coord). La paradoja de la calidad. Alimentos mexicanos en América del Norte. México, El Colegio de México, Centro de Estudios Demográficos, Urbanos y Ambientales.

Morelos-Gómez, José, Tomás José Fontalvo, y Juan Carlos Vergara. 2013. Incidencia de la certificación ISO 9001 en los indicadores de productividad y utilidad financiera de empresas de la zona industrial de Mamonal en Cartagena. Estudios Gerenciales. Vol. 29, Núm. 126.

Moura-Duarte, André Luís, Luiz Artur Ledur-Brito, Luiz Carlos Di-Serio, y Guilherme Silveira-Martins. 2011. Operational practices and financial performance: An empirical analysis of Brazilian manufacturing companies. Brazilian Administration Review. Vol. 8, Núm. 4.

Oliva-Olivera, Ángel. 2013. Proyecto de reducción de costos mediante el seis sigma y su impacto financiero, México, Universidad Autónoma de Querétaro. 119 p.

Pérez-Méndez, José Antonio, y Ángel Machado-Cabezas. 1987. Relationship between management information systems and corporate performance. Revista de Contabilidad. Vol. 18, Núm. 1, 2015.

Porter, Michael. Ventaja competitiva, México, Editorial CECSA. $556 \mathrm{p}$.

Rodríguez-Gómez, Guadalupe. 2012. La calidad en los sistemas agroalimentarios en América del Norte. In: Appendini Kirsten, y Rodríguez-Gómez Guadalupe (coord). La paradoja de la calidad. Alimentos mexicanos en América del Norte. México, El Colegio de México, Centro de Estudios Demográficos, Urbanos y Ambientales.

Sánchez-Ollero, José Luis, Alejandro García-Pozo, y Andrés Marchante-Mera. 2014. Análisis de la incidencia de las certificaciones de calidad sobre la productividad de los hoteles en Andalucía. Universia Business Review. Núm. 44, cuarto trimestres.

Santamaría-Escobar, Álvaro Enrique, y Patricia Aylin PertuzMartínez. 2013. Certificación de la calidad ISO 9001: Clave del mejoramiento del desempeño empresarial. Vol. 21.

SHCP. 1999. Plan Nacional de Desarrollo 2013-2018. México, Diario Oficial de la Federación, 2013.

Shepherd, William. The economics of industrial organization, Estados Unidos, Waveland Press, 447 p.

Shepherd, William, y Joanna Shepherd. 2003. The economics of industrial organization, Estados Unidos, Waveland Press. 440 p.

Smith-Ramírez, Eric Arturo. 2015. Evaluación del impacto de la estrategía de calidad en el desemepeńo de la organización y modelo para la industria maquiladora en Nogales, México, Universidad Popular Autónoma del Estado de Puebla. 276 p.

Taddei, Cristina. 2008. Estrategias de mercado en la industria alimentaria, México, Centro de Investigación en Alimentación y Desarrollo. 298 p.

Tarí-Guilló, Juan José, y Jorge Pereira-Moliner. 2012. Calidad y rentabilidad. Análisis del certificado Q en las cadenas hoteleras. Universia Business Review. Núm. 34, Segundo trimestre.

Terziovski, Milé, y Damien Power. 1997. Increasing ISO 9000 certification benefits: A continuous improvement approach. International Journal of Quality \& Reliability Management. Vol. 21, Núm. 2.

Tolamatl-Michcol, Jacobo, David Gallardo-Garcia, José Antonio Varela-Loyola, y Elena Flores-Ávila. 2011. Aplicación de seis sigma en una microempresa del ramo automotriz. Conciencia Tecnológica. Núm. 42. 